„Przekłady Literatur Słowiańskich”. T. 11, cz. 1, s. 1-24

ISSN 2353-9763 (wersja elektroniczna)

DOI https://doi.org/10.31261/PLS.2021.11.01.14

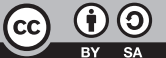

\title{
»Rekonsi«: prevodi Kosovelovih konsov in Chestermanove prevajalske strategije
}

\section{The "Re-Conses": Translations of Srečko Kosovel's Constructivist Poems and Andrew Chesterman's Translation Strategies}

\author{
Robert Grošelj \\ iD https://orcid.org/0000-0002-4105-2013 \\ UNIVERSITY OF LJUBLJANA \\ robert.groselj@ff.uni-lj.si
}

Datum prijave: 13. 1.2021 ｜ Datum recenzije in sprejema: 26. 5.2021

\begin{abstract}
The article deals with the analysis of Italian and Croatian translations of constructivist poems (the "conses") by Srečko Kosovel, one of the most important Slovene poets. The translations of selected Kosovel's constructivist poems are analysed by using Andrew Chesterman's translation strategies. The analysis shows that, for the most part, in Croatian and Italian translations the literal translation strategy prevails, with Italian translations including more frequently other translation possibilities. In general, both translators have strived to preserve the multifaceted aspects of Kosovel's constructivist poems by adopting a predominantly foreignising translation approach.
\end{abstract}

KEYWORDS | Srečko Kosovel, constructivist poetry, Italian translation, Croatian translation, translation strategies, Andrew Chesterman 
Eden najpomembnejših slovenskih književnikov v 20. stoletju je Srečko Kosovel, še posebej po zaslugi svojih konstruktivističnih pesmi, ki jih je šele leta 1967 objavil literarni zgodovinar Anton Ocvirk. Te pesmi so razkrile izvirno in moderno pesniško ustvarjalnost, zaradi katere je slovenska avantgarda po drugi svetovni vojni Kosovela razglasila za svojega predhodnika, hkrati pa je postal pomemben člen evropskega konstruktivizma. Kosovelova dela so bila in so še vedno deležna pozornosti številnih raziskovalcev, obenem pa tudi prevajalcev, o čemer pričajo knjižni prevodi v najmanj 22 jezikov, od angleščine do retoromanščine.

Kosovelova poezija in njeni prevodi so navdahnili tudi pričujoči prispevek, v katerem raziskujem, kakšne prevajalske strategije (po A. Chestermanu) sta pri prevajanju Kosovelovih konstruktivističnih pesmi, t. i. konsov, v hrvaščino in italijanščino uporabila dva izmed največjih medjezikovnih in medkulturnih posredovalcev Kosovelove poezije, Jolka Milič in Josip Osti. Prispevek bo na takšen način dopolnil obstoječe raziskave ( $\mathrm{v}$ prvi vrsti prevodne) recepcije Kosovelove poezije v tujih jezikih.

\section{Gradivo in metodologija}

Analiza prevodnega razmerja med Kosovelovimi konsi in njihovimi prevodi — »rekonsi« — v izbranih jezikih se nanaša na sedem pesmi: Kons: $M A \bar{S}$ (Naša mačka), Kons: N, Kons (Tiger), Kons: 4, Kons (Truden evropski človek), Kons.Ikarus in Kons (Premalo gibanja). Njihova izbira je pragmatična: gre za konstruktivistične pesmi s poimenovanjem kons v naslovu, ki se pojavljajo tako $\mathrm{v}$ hrvaškem prevodu Integrali (prevajalec Josip Osti) kot v italijanskem Ves svet je kakor - Tutto il mondo è come (prevajalka Jolka Milič).

Analiza prevodnih sprememb med izhodiščnimi in ciljnimi pesmimi temelji na modelu prevajalskih strategij A. Chestermana. V analizi so bile izhodiščne pesmi, ki jih uvajajo kratki vsebinsko-interpretativni in formalni opisi, primerjane s prevodi - po posameznih verzih so bile opredeljene Chestermanove prevajalske strategije (v prvi vrsti skladenjske), ki so bile nato komentirane po pesmih (kvalitativno in kvantitativno) in za vse analizirane konse skupaj. Analizi prevajalskih strategij sledi osvetlitev razlik med hrvaškimi in italijanskimi prevodi ter opredelitev prevodov z vidika celostnega odnosa do izvirnih pesmi (po F. R. Jonesu, A. Lefeveru in J. Holmesu) in globalnega prevajalskega pristopa. 


\subsection{Prevajanje poezije in prevajalske strategije A. Chestermana}

Poezija ima v prevajanju in prevodoslovju posebno mesto: gre za literarno zvrst, ki jo zaznamuje izrazita formalna in vsebinska kompleksnost. Sestavine prve so ritem, metrum, stopica, verz, rima, kadenca, refren, glasovno barvanje, kitica, bolj ali manj konvencionalna oblika, posledica česar sta izraziti "glasbenost « in vizualna vpadljivost. ${ }^{1} \mathrm{~V}$ zapleteni obliki pa se nahaja nič manj zapletena vsebina, izražena s prepletom raznovrstnih sredstev, ki tvorijo poseben sistem: besedje, njegov položaj, vrsta in zaznamovanost, tropi, besedne igre, leksikalni kontrast, kršenje pomenske in slovnične vezljivosti. ${ }^{2} \mathrm{~V}$ nobeni drugi zvrsti ni estetska informacija (funkciji poezije sta sicer lahko še zabava in povečano čustveno-intelektualno doživetje) ${ }^{3}$ predstavljena s takšno koncentracijo sredstev, ${ }^{4}$ kar predvideva povečano pozornost bralca in omogoča interpretativno raznolikost. ${ }^{5}$ Zaradi takšne besedilne zapletenosti (h kateri sodi tudi kontekst pesmi) je prevajanje poezije kompleksna dejavnost, ki zahteva visoko usposobljenost. ${ }^{6}$

Različno razmerje med izvirnim in ciljnim besedilom omogoča vzpostavitev treh tipov prevoda pesmi: ${ }^{7}$ (1) dobesedni ali prozni prevod poustvari izhodiščni pomen in opusti izhodiščne pesniške značilnosti (pogosto je ob pesmi v izvirniku); (2) adaptacija, verzija ali imitacija spremenijo ali opustijo ključne pomenske elemente, tudi pesniške značilnosti izhodiščnega besedila v korist učinkovitosti ciljne pesmi; (3) poustvarjalni prevod skuša poustvariti pomenske in pesniške lastnosti izvirnika v ciljni pesmi. ${ }^{8}$ Natančnejša je tipologija strategij A. Lefevera: (1) fonemski prevod poustvarja izhodiščno glasovno podobo in vsebuje sprejemljivo parafraziranje pomena; (2) verodostojni prevod poudarja prevajanje besede za besedo; (3) metrični prevod je pozoren na izhodiščni metrum; (4) prevod v prozi sledi izhodiščnemu pomenu, $v$ škodo glasovne podobe;

1 I. S. Alekseeva, 2008: Tekst i perevod. Voprosy teorii. Moskva, Meždunarodnye otnošenija, str. 138-139. Prim. še S. Bassnett, 2002: Translation Studies. London/New York, Routledge, str. 106; F. R. Jones, 2011: Poetry translation. V: Y. Gambier, L. van Doorslaer, ur.: Handbook of Translation Studies 2. Amsterdam/Philadelphia, John Benjamins, str. 117.

2 I. S. Alekseeva, 2008: Tekst ..., str. 140.

3 F. R. Jones, 2011: Poetry ..., str. 117.

4 I. S. Alekseeva, 2008: Tekst ..., str. 140. Prim. S. Bassnett, 2002: Translation ..., str. 108.

5 J. Boase-Beier, 2013: Poetry translation. V: C. Millán, F. Bartrina, ed.: The Routledge Handbook of Translation Studies. London/New York, Routledge, str. 477, 483.

6 F. R. Jones, 2011: Poetry ..., str. 119-120. Prim. J. Boase-Beier, 2013: Poetry ..., str. $477-478$.

7 F. R. Jones, 2011: Poetry ..., str. 118-119.

8 Ob poustvarjalnem prevodu potekajo številne debate, npr. o tem, katere elemente izhodiščnega besedila je bolje ohraniti, o težavnosti njihovega prevajanja, o vplivu literarnih norm. Prim. J. Boase-Beier, 2013: Poetry ..., str. 480—481. 
(5) ritmični prevod ohranja metrum in rimo; (6) prevod s svobodnim verzom;

(7) interpretacija vključuje verzije, ki ohranjajo bistvo izhodiščne pesmi, ne pa oblike, in imitacije, ko prevajalec ustvari svojo pesem (z izvirnikom ima lahko skupna le naslov in »izhodiščno točko «). ${ }^{9}$

Drugačen - nekako v okvirih Lefeverovega prezapisovanja (angl. rewriting) - je diapazon metabesedilnih možnosti (od interpretacije do pesnjenja) J. Holmesa: (1) kritična razprava o pesmi v jeziku pesmi, (2) kritična razprava o pesmi v tujem jeziku, (3) prevod $v$ prozi, (4) prevod $v$ verzih (metapesem), (5) imitacija, (6) pesem o pesmi, ki se delno naslanja na izvirnik, in (7) prevod, $k i$ ga je v obrisih navdahnil izvirnik. ${ }^{10}$ Pri poustvarjanju formalnih vzorcev J. Holmes prepoznava štiri pristope: (1) mimetičnega $\mathrm{z}$ reprodukcijo izhodiščne oblike (ki ne zagotavlja istega učinka); ${ }^{11}$ (2) analogičnega s funkcijsko podobno ciljno obliko; (3) organskega z obliko, ki se zdi prevajalcu po vsebini najbolj ustrezna; (4) deviantnega (tujega) z obliko, ki ni implicitno prisotna v izvirniku. ${ }^{12}$ Različne možnosti so predmet debat o etiki, katere razpon predstavljata lojalnost izvirniku in odgovornost, da v ciljnem jeziku nastane pesniško relevantna pesem. ${ }^{13}$ Ne glede na strategijo ali pristop pa kompleksnost poezije pomeni, da se pri njenem prevajanju ni mogoče izogniti premikom ali izgubam. ${ }^{14}$

Ciljno besedilo - npr. pesem - je rezultat preoblikovanja jezikovnega gradiva, ki ga usmerjajo prevajalski postopki. Eno izmed njihovih klasifikacij, ki ima praktično vrednost in temelji na bogati teoriji »formalnih premikov«, je predlagal A. Chesterman. Njegove "produkcijske prevajalske strategije« (lahko bi govorili o prevajalskih postopkih) se nanašajo na spremembe, do katerih prihaja pri preubeseditvi in vključujejo »izbiro « med možnostmi (niso jezikovno pogojene spremembe). Delijo se na tri vrste: skladenjske, pomenske in pragmatične (vrste strategij se lahko med seboj prepletajo); prve zadevajo obliko, druge pomen, tretje pa se nanašajo na izbiro informacije, ki jo vodi prevajalčevo poznavanje predvidene publike. ${ }^{15}$ Za pričujočo študijo so najbolj relevantne skladenjske strategije, ki se delijo na deset kategorij: (1) verodostojni prevod je najbližji izho-

9 Prim. S. Bassnett, 2002: Translation ..., str. 87; S. Arduini, U. Stecconi, 2007: Manuale di traduzione. Roma, Carocci, str. 26.

10 J. Holmes, 1988: Translated!: Papers on Literary Translation and Translation Studies. Amsterdam, Rodopi, str. 23-24. Prim. B. Hatim, 2001: Teaching and Researching Translation. Harlow, Pearson Education, str. 58; S. Bassnett, 2002: Translation ..., str. 105.

11 Prim. Bassnett, 2002: Translation ..., str. 96.

12 J. Holmes, 1988: Translated! ..., str. 26-27. Prim. B. Hatim, 2001: Teaching ..., str. 59; S. Arduini, U. Stecconi, 2007: Manuale ..., str. 26.

13 F. R. Jones, 2011: Poetry ..., str. 119.

14 S. Bassnett, 2002: Translation ..., str. 89; I. S. Alekseeva, 2008: Tekst ..., str. 140.

15 A. Chesterman, 1997: Memes of Translation. Amsterdam/Philadelphia, John Benjamins, str. 94, 101, 107. 
diščni obliki, hkrati pa je slovnično pravilen (ker ga imajo nekateri prevodoslovci za privzeto - angl. default - izbiro, ga v članku imenujem privzeti prevod); (2) prevzeti elementi, kalki; (3) transpozicija se nanaša na spremembo besednih vrst; (4) spremembe enote pomenijo prehode med morfemom, besedo, zvezo, stavkom, stavčno zvezo, odstavkom; (5) besednozvezne spremembe so spremembe na ravni besedne zveze (npr. število, določnost, modifikacija v samostalniški zvezi; oseba, čas in naklon v glagolski zvezi); (6) spremembe stavčne zgradbe se nanašajo na stavčne člene, besedni red, glagolski način, (pol)stavčnost, (ne) prehodnost; (7) stavčnozvezne spremembe prizadevajo razmerje med glavnim in odvisnim stavkom, med tipi odvisnikov; (8) spremembe kohezije zajemajo znotrajbesedilno referenco, elipso, substitucijo, pozaimljanje, ponavljanje, rabo povezovalcev; (9) spremembe ravni vključujejo premike jezikovnih elementov med glasoslovjem, oblikoslovjem, skladnjo in besedjem; (10) sprememba sheme se nanaša na ohranitev, spremembo, izpust ali vpeljevanje retoričnih shem, kot so npr. paralelizem, ponavljanje, aliteracija, metrum. ${ }^{16}$

Med ostalimi Chestermanovimi postopki naj izpostavim pomensko strategijo sinonimije, izbiro pomensko bližnjega izraza namesto očitne ustreznice, in pragmatično strategijo informacijske spremembe, ko pride do dodajanja informacije, relevantne za ciljnega bralca, ali izpusta nerelevantne informacije. ${ }^{17}$

\section{Srečko Kosovel in njegovi konsi}

Srečko Kosovel (1904-1926) je eno najpomembnejših imen slovenske književnosti: bil je v prvi vrsti pesnik (njegove poezije vključujejo tudi pesmi v prozi in otroške pesmi), pisal pa je tudi kratko prozo in eseje. Po otroštvu na domačem Krasu se je vpisal na ljubljansko realko, nato pa na Filozofsko fakulteto v Ljubljani, kjer je študiral romanistiko, filozofijo in slavistiko, zanimala pa ga je tudi pedagogika. Kosovelova mladost je časovno sovpadla s prvo svetovno vojno, ki je napovedovala - $\mathrm{z}$ vsemi nerešenimi vprašanji - grozote druge svetovne vojne. V letih 1925-1926 je Kosovel, sit fašističnega zatiranja na Primorskem, represivne Kraljevine SHS, evropskega imperializma in slovenske razdeljenosti med klerikalizmom in liberalizmom, zavzel skoraj oporečniško držo (v smeri socialističnega aktivizma) ter nihal med poezijo in politično dejavnostjo. Kosovel je do konca življenja, kljub oviram bližnjih in založnikov, vztrajal v svojem književnem delovanju, prepričan v svoje pesniško poslanstvo.

16 A. Chesterman, 1997: Memes ..., str. 94-101.

17 A. Chesterman, 1997: Memes ..., str. 102, 109-110. 
Kosovelova poezija se deli v tri sklope, ki se med seboj spiralno navezujejo. ${ }^{18}$ Prvi sklop predstavlja impresionizem, v katerem prevladujejo podobe Krasa (kot življenjske stvarnosti), ki imajo pogosto simboličen pomen in s katerimi Kosovel prehaja v ekspresionistično izražanje občutij in odnosa do sveta. Kot ekspresionist Kosovel impresije nadomesti z eksistencialnimi in etičnimi vprašanji - o smrti, problematiki človeka in socialnih sprememb, kolektivni apokalipsi ipd. - v pogosto raztrgani, neharmonični obliki.

Med 1924 in 1925 je Kosovel začel eksperimentirati s pesniškimi konstrukcijami, ki jih je imel zaradi sinteze literarnega konstruktivizma in tradicije za svojevrsten doprinos k evropskemu konstruktivizmu. Konstruktivistične pesmi (nekatere se imenujejo konsi) stopnjujejo Kosovelov ekspresionizem (dopolnjujejo ga izbrane dadaistične, nadrealistične in futuristične prvine). Motivi in ideje ostajajo načeloma isti, ${ }^{19}$ a v drugačni - neestetski in tehnični - obliki: konstrukcije so pesmi, na videz brez logične zveze sestavljene iz parol, gesel, tehničnih ali matematičnih obrazcev (včasih simbolov), tipografije, tudi nadrealističnih podob, a hkrati organske tvorbe (po obliki, vsebini in jeziku). Kosovelove konstruktivistične pesmi predstavljajo najmodernejši tip slovenske poezije v tem času, ker pa so dolgo ostale neobjavljene, niso imele vpliva na sočasno poezijo. Zadnjo fazo Kosovelovega ustvarjanja predstavljajo socialnorevolucionarne pesmi, t. i. integrali, ki jih zaznamujejo realistični okviri in napoved socrealizma.

Kosovel ni nikoli objavil načrtovane pesniške zbirke Zlati čoln - za prvo izdajo njegove poezije z naslovom Pesmi leta 1927 je zaslužen A. Gspan. V nadaljevanju je Kosovelova dela objavljal A. Ocvirk: leta 1931 so izšle Izbrane pesmi, leta 1946 prvi del Zbranega dela (druga izdaja 1964), a brez avantgardističnih pesmi, ki so bile prvič objavljene leta 1967 v posebni zbirki Integrali '26. Pesmi so takoj pritegnile pozornost sodobnih slovenskih avtorjev, ki so v Kosovelu videli revolucionarnega modernista in svojega predhodnika. Pozneje sta izšla še dva dela Kosovelovih Zbranih del (1974, 1977). ${ }^{20}$

$18 \mathrm{~V}$ strokovni literaturi se pojavljata dve različni globalni delitvi Kosovelovega ustvarjanja na tri sklope: impresionizem, ekspresionizem, konstruktivizem in impresionizem, konstruktivizem, integrali.

19 F. Zadravec izpostavlja mestno in tehnično civilizacijo, demoralizacijo in materializacijo (dekadenco) Evrope, politično moralo (Slovenije, Jugoslavije in Evrope), ki obsega lažnost meščanske demokracije, nacionalizme, fašizem. Prim. F. Zadravec, 1986: Srečko Kosovel 1904-1926. Koper/Trst, Založništvo Lipa/ZTT, str. 159-187.

20 J. Kos, 1976: Pregled slovenskega slovstva. Ljubljana, DZS, str. 329-334; F. Zadravec, 1986: Srečko Kosovel ..., str. 11-305; N. Kocijančič Pokorn, 1998: Beyond the Avant-Garde and Expressionism: Srečko Kosovel's Integrals. V: S. Kosovel: Integrals. N. Kocijančič Pokorn, K. Jerin, P. Burt, prev. Ljubljana, Slovene Writers’ Association, str. 11-19; J. Vrečko, 2011: Srečko Kosovel. Monografija. Ljubljana, Založba ZRC, 


\section{Prevodi Kosovelovih del v tuje jezike (s poudarkom na analiziranih prevodih)}

Prevodi Kosovelovih del so bili v knjižni obliki objavljeni — po podatkih Javne agencije za knjigo RS in bibliografskega sistema COBISS - v najmanj 22 jezikih: $\mathrm{v}$ angleščini, arabščini, beloruščini, bosanščini, češčini, esperantu, francoščini, grščini, hrvaščini, italijanščini, katalonščini, kitajščini, madžarščini, makedonščini, nemščini, poljščini, retoromanščini, romunščini, slovaščini, srbohrvaščini, srbščini in španščini. ${ }^{21}$ Med jezike, v katerih je največ izdaj Kosovelovih del, sodijo italijanščina, osrednjejužnoslovanski jeziki (s štokavsko osnovo; srbohrvaščina, bosanščina, hrvaščina, srbščina), nemščina in angleščina.

Kosovelovi prevodi v osrednjejužnoslovanske jezike so delo številnih prevajalcev, med katerimi izstopa Josip Osti, ki je prevedel tudi analizirane hrvaške prevode. ${ }^{22}$ J. Osti (1945-2021) je bil pesnik, pisatelj, esejist, kolumnist in prevajalec, ki je pisal v bosanščini (v svojem »jeziku spominov«) in slovenščini. Za svoja dela, prevedena v mnoge jezike, je prejel ugledne slovenske, jugoslovanske in mednarodne literarne nagrade. Bil je zelo plodovit prevajalec - prevedel je več kot 140 slovenskih del, proznih in pesniških, starejših in sodobnih. Posebno mesto v Ostijevem prevajalskem opusu zaseda Kosovel s sedmimi izdajami: Čovjek iza Brda (Banja Luka, 1989), Integrali (Ljubljana, 1993), Integrali (Sarajevo, 2003), Slutnja smrti (Cetinje, 2013), Integrali (Beograd, 2016), Integrali (Zagreb, 2019) in Pisma sestri Karmeli (Ljubljana, 1995). ${ }^{23}$ Analizirani prevodi Kosovelovih konsov so izšli v zbirki Integrali, ki jo je leta 2019 izdala založba MeandarMedia v Zagrebu; konsi so bili prevedeni po drugi knjigi Zbranih del

ZRC SAZU, str. 7-485. M. Košuta, 2011: Come un razzo rosso ... V: S. Kosovel: Ostri ritmi - Aspri ritmi. J. Milič, ur. in prev. Trieste, ZTT EST, str. 7-53.

21 Prim. bazo prevodov Javne agencije za knjigo RS (https://www.jakrs.si/) in bibliografski sistem COBISS (https://plus.si.cobiss.net/). - O prevodih so nastale mnoge prevodoslovno-prevodne študije: npr. N. Kocijančič Pokorn, P. Burt, K. Jerin so pisali o svojih angleških prevodih, M. Grgič, M. Ožbot, M. Pirjevec, J. Zoltan o italijanskih prevodih, S. Borovnik o nemških, K. Šalamun Biedrzycka o francoskih, K. Bucka o poljskih, S. Repar o slovaških, S. Martín in J. Markič pa o španskih prevodih.

22 Za ostale prevode so zaslužni G. Janjušević in D. Poznanović (1964, 1975), S. Mihalić (1980), G. Janjušević (1981), A. M. Kobal (1981), B. Pavlović (1986), I. Bekrić (1997, 2004), R. Dabo (2004).

23 Prim. bibliografski sistem COBISS (https://plus.si.cobiss.net/); L. Dimkovska, 2005: Književnost priseljencev $v$ Sloveniji - njene značilnosti in položaj v slovenski kulturi. »Dve domovini«, št. 22, str. 60-63; M. Mugerli, 2005: Slovenski prevodi literarnih del priseljenskih avtorjev po letu 1990. »Dve domovini«, št. 22, str. 86; P. Pogorevc, ur., 2006: Ten Authors from Slovenia. Ljubljana, Chamber of Commerce and Industry of Slovenia, str. 37. 
(1974), dodane pa so jim tri pesmi iz izdaje leta $1967 .{ }^{24}$ Prevode dopolnjujejo spremna beseda J. Ostija (Pjesnik ekstaze smrti i žudnje za novim životom koji je istovremeno bio i nije bio avantgardist), opombi o avtorju in prevajalcu.

Bera Kosovelovih del v italijanščini obsega (po mojem štetju) kar 17 knjižnih izdaj, za več kot polovico pa je zaslužna Jolka Milič, katere prevod je analiziran v prispevku. ${ }^{25}$ J. Milič (1926-2021), literarna kritičarka, esejistka, pesnica in prevajalka, je bila ena največjih posredovalk med slovensko in italijansko literaturo. ${ }^{26}$ Prevajala je zlasti poezijo - iz italijanščine (delno iz francoščine, španščine) v slovenščino ter iz slovenščine (včasih iz bosanščine) v italijanščino; prevedla je dela več kot 170 pesnikov in pesnic slovenske in svetovne književnosti. Za svoje delo je prejela mnoga priznanja v Sloveniji in Italiji. ${ }^{27}$ J. Milič se je poglobljeno posvečala Kosovelu, na kar opozarja devet knjižnih izdaj prevodov: Poesie di velluto e Integrali (s P. Merkùjem; Trst, 1972), Poesie e integrali (Trst, 1976), Ves svet je kakor - Tutto il mondo è come (Sežana, 2000), Kons in Il mio canto - Moja pesem (Trst, 2002), Kons 2 (Trst, 2003), Ostri ritmi - Aspri ritmi (Trst, 2011, 2020), Non chiedermi cosè la vita, vivi! (Trst, 2015). ${ }^{28}$ Analizirani prevodi se nahajajo v zbirki Ves svet je kakor - Tutto il mondo è come, ki jo je leta 2000 izdala Občina Sežana. ${ }^{29}$ Dvojezična zbirka (v slovenščini in italijanščini) vsebuje 87 pesmi in 114 integralov, predgovor Kosovel, kraški poet in avantgardist profesorja J. Vrečka, podatke o pesniku, nekaj

24 S. Kosovel, 2019: Integrali. J. Osti, prev. Zagreb, MeandarMedia, str. 191.

25 Kosovelova dela so v italijanščino prevajali še P. Merkù (skupaj z J. Milič; 1972), L. Morandini, M. Vertovec, M. Kravos (1979, 1980), G. Brazzoduro (1989), M. Obit (1999, $2017,2020)$ in D. Betocchi $(2014,2016)$.

26 Z. Jan, 2000: Poznavanje slovenske književnosti v Italiji po letu 1945. Ljubljana, Založba Rokus/Slavistično društvo Slovenije, str. 18-22, 103-113, 182-186; M. Košuta, 2014: »Le drugo ime za ljubezen ... «. Novejše knjižno italijanjenje slovenskega leposlovja (2000-2013). »Przekłady literatur słowiańskich«, št. 5/1, str. 224.

27 Prim. biografski leksikon Primorci.si (http://www.primorci.si/); regijski portal Kamra (https://www.kamra.si/ digitalne-zbirke.html).

28 Prim. bibliografski sistem COBISS (https://plus.si.cobiss.net/). O posredovanju Kosovelove poezije v italijanščino in J. Milič, prim. Z. Jan, 2001: Cankar, Kosovel, Zlobec in Ljubka Šorli pri Italijanih ter Bibliografski dodatek. Ljubljana, Založba Rokus/Slavistično društvo Slovenije, str. 25-42. Prevode J. Milič je z vidika razmerja med podomačevanjem in potujevanjem ter položaja $\mathrm{v}$ italijanskem kulturno-literarnem prostoru obravnavala M. Ožbot. Prim. M. Ožbot, 2011: Dwarfs in Giants' Lands: Some Observations on Translating Minor Literatures into High-Impact Cultures - The Case of Slovene Literature in Italy. »Meta«, št. 56/3, str. 516, 521; M. Ožbot, 2018: O Kosovelovi "evropskosti« in še posebej o dveh nedavnih prevodih njegove poezije $v$ italijanščino. V: I. Žunkovič, T. Smolej, ur.: Življenje med antiko in avantgardo: zbornik ob jubileju Janeza Vrečka. Ljubljana, Znanstvena založba FF, str. 210-211.

29 S. Kosovel, 2000: Ves svet je kakor - Tutto il mondo è come. J. Milič, ur. in prev. Sežana, Občina Sežana. 
slikovnega gradiva, pesmi v Kosovelov spomin, kritična mnenja in osnovno bibliografijo.

\section{Analiza}

Prevodi izbranih Kosovelovih konsov (pogl. 1) so analizirani glede na Chestermanove prevajalske strategije - predvsem gre za skladenjske strategije, ki jih dopolnjujeta pomenska strategija sinonimije ${ }^{30}$ in pragmatična sprememba informacije (pogl. 1.1); ločeno opozarjam na retorične sheme in tipografijo. $\mathrm{Na}$ koncu sledi opredelitev »rekonsov« po obliki (tj. po dolžini verzov) ${ }^{31}$ in tipu povedi (enostavčna, dvostavčna, nestavčna ipd.).

\subsection{Kons: MĀ̄ (Naša mačka)}

Ljubezenski Kons: MAS̄ (Naša mačka) Kosovel gradi z analogijo: subjekt mačkine zelene oči šaljivo primerja $\mathrm{z}$ zelenimi očmi ljubice, zeleno kuščarico z zelenim pasom ljubice, ljubico z mačko, na koncu pa pomenljivo izjavi, da jo - Mačko? Ljubico? - ima v naročju. ${ }^{32}$ B. Tokarz poudari mačko-ljubico, ki spominja na da Vincijevo Damo s hermelinom, igro med dvopomenskostjo silepsisa in večpomenskostjo simbola, ki sproža medbesedilno igro $\mathrm{z}$ besedili kulture. ${ }^{33}$ Kons ima tri kitice s 15 (6, 7 in 2 ) dokaj kratkimi verzi ${ }^{34}$ in pet povedi (3 enostavčne, 2 nestavčni/medmetni). Med retoričnimi shemami se pojavlja končno ponavljanje oči (v. 2, 4 in 12), kombinacija rime in glasovne podobnosti pas lase - stas - jaz (v. 9, 11, 13, 15) ter paralelizem z mnogovezjem: in zlate lase / in zelene oči / in vitek stas (v. 11-13).

30 Kot sinonimijo obravnavam - gre za praktično metodološko rešitev - leksikalno ustreznico, ki se pomensko jasneje loči od izhodiščnega izraza.

31 Dolžino verzov določa število zlogov. Če je po dolžini enakih več kot $90 \%$ verzov (enakost vključuje tudi odklon za en zlog), govorim o ujemalni obliki, pri več kot $60 \%$ enakih verzov o podobnosti, pri manj kot $60 \%$ pa o razlikovanju.

32 F. Zadravec, 1986: Srečko Kosovel ..., str. 67, 198. B. Tokarz omenja še ritmično stilizacijo v smeri ljudske pesmi. Prim. B. Tokarz, 2004: Między destrukcją a konstrukcją. O poezji Srečka Kosovela w kontekście konstruktywistycznym. Katowice, Wydawnictwo Uniwersytetu Śląskiego, str. 60.

33 B. Tokarz, 2004: Między destrukcja ..., str. 114.

34 Število zlogov po verzih - izvirnik: 4/6/5/3/3/7/4/5/5/6/5/5/4/ 5/4; hrv. prevod: $4 / 6 / 6 / 3 / 3 / 7 / 2 / 4 / 5 / 6 / 5 / 5 / 4 / 5 / 5$; it. prevod: $5 / 4 / 6 / 5 / 7 / 7 / 4 / 4 / 7 / 7 / 6 / 4 / 7 / 7 / 3$. 
$\mathrm{V}$ hrvaščini je $\mathrm{v}$ vseh verzih privzeti prevod. Le na ravni retoričnih shem prihaja do delne spremembe rime in glasovne podobnosti: pas - kosu - stas ja (na koncu asonanca; v. 9, 11, 13, 15). Po obliki (gl. op. 34) in tipu povedi se izvirnik in prevod ujemata.

$\mathrm{V}$ italijanščini se privzeti prevod pojavlja $\mathrm{v}$ desetih verzih, pet verzov pa zaznamujejo druge skladenjske strategije: $v$ štirih verzih $(5-6,14-15)$ se spremeni stavčna zgradba (besedni red) in $\mathrm{v}$ treh enota (pridevnik večerno - predložna zveza di una sera v. 6; pridevnik zlati - predložna zveza d’oro v. 11; medmet ha - medmetna zveza ah ah v. 14), gl. 1. V enem verzu nastopa sinonimija (vitek stas - vitino sottile v. 13), gl. 2. Verz 3 vključuje pragmatično spremembo informacije - v opombi prevajalka razloži zamenjavo Kosovelovega ametista z Ocvirkovim malahitom, gl. 3. Od retoričnih shem je ohranjen paralelizem e capelli d’oro / e occhi verdi / e un vitino sottile (v. 11-13; a s predložno zvezo d’oro). Po obliki sta si izvirnik in prevod načeloma podobna (gl. op. 34), po tipu povedi pa se ujemata.

(1) Ha, in njo nosim / v naročju jaz. - Ah ah, e io la porto / in braccio.

(v. 14-15)

(2) in vitek stas - e un vitino sottile (v. 13)

(3) kot malachita, - come malachite, ${ }^{\star}$ (v. 3 )

* Nel testo originale il poeta, per errore, paragona gli occhi verdi all'ametista. Il curatore dell'opera omnia Anton Ocvirk l'ha sostituito con malachite ( $\mathrm{v}$ originalnem besedilu pesnik, zmotno, zelene oči primerja $\mathrm{z}$ ametistom. Urednik zbranega dela Anton Ocvirk ga je zamenjal z malahitom).

\subsection{Kons: $\mathrm{N}$}

V konsu, katerega osrednji motiv je ljubezenski, naj bi subjekt le mimogrede ugotavljal neka objektivna stanja. ${ }^{35}$ Dogajalni prostor je morje, ki ga preleti bela golobica - subjektovo mirovanje prekine napoved pozitivnosti (zmaga), ki pa morda prinaša tudi razočaranje (žareče srce, na katerega padajo sinji kristali rose). Nato se s svojimi drobnimi nožicami pojavi ona, ki oživi subjektovo statičnost (jadrnica, morje), kar prinese veselje in sproži navdušujoč poziv k potovanju-plovbi, morda kot odkrivanju novega (skozi Gibraltar v Ameriko). ${ }^{36}$

35 F. Zadravec, 1986: Srečko Kosovel ..., str. 200-201.

36 Prim. sicer kritičnost do "amerikaidnosti« (erotizacije) v F. Zadravec, 1986: Srečko Kosovel ..., str. $168-172$. 
Kons sestavlja blok 14 različno dolgih verzov ${ }^{37}$ in devetih različno kompleksnih povedi (5 enostavčnih, 3 dvostavčne in 1 nestavčna). $V$ konsu ni izrazitih retoričnih shem.

Hrvaški prevod lahko v celoti označim kot privzet. Po obliki sta si izvirnik in prevod zelo podobna (gl. op. 37), po tipu povedi pa sta ujemalna.

$\mathrm{V}$ italijanščini se privzeti prevod nahaja $\mathrm{v}$ osmih verzih, $\mathrm{v}$ šestih pa druge skladenjske strategije. Štirikrat bi lahko govorili o spremembi stavčne zgradbe - dvakrat se spremeni besedni red $(v .9,11)$, po enkrat stavčni členi in prehodnost (v. 7), gl. 5-7; trikrat se pojavi sprememba kohezije (si stopila - sei salita a bordo z meronimom jadrnice v. 8; izpust zaimkov $t a$, $t i$ v. 3,11 ), dvakrat sprememba enote (glagol vztrepetavati - glagolska zveza fare vibrare v. 7; glagol zašumeti - glagolska zveza mettersi a sussurrare v. 10) in enkrat sprememba stavčne zveze (posledično podredje - vezalno priredje v. 7), gl. 6-7. Verz 7 zaznamujeta dve sinonimiji ( $d a-e$; vztrepetavati - vzročnik fare vibrare), gl. 7. Oblikovno sta izvirnik in prevod načeloma podobna (gl. op. 37), po tipu povedi pa ujemalna (z izjemo stavčne zveze iz v. 7).

(5) Veselje je naše. - Nostra è l’allegria. (v. 9)

(6) ko si ti stopila z obali - quando dalla riva sei salita (v. 11)

(7) da vztrepetava žolto jadro? - e fa vibrare la vela gialla? (v. 7)

\subsection{Kons (Tiger)}

Kons se začne s podobo tigra, ki raztrga krotilca, in opozorilom, da se narava ne da ukalupljati (dresirati). Podoba je prenesena na človeka v mehaniziranem, tehnologiziranem svetu, pri čemer je opozorjeno na nevarnost iz drame K. Čapka Rossum's Universal Robots (R. U. R.), ko se umetni stvori, izdelani kot humunkulusi, uprejo svojim gospodarjem. ${ }^{38}$ Ravnovesje sveta se skriva v dobroti - do narave, živali, človeka. V zaključku pesmi sledi poziv tistim, ki so odgovorni za »mehanizacijo«sveta (dompter), naj se umaknejo, v ospredje pa stopi človek. Subjekt pokliče naslovnike k uporu proti mehanizaciji, proti taylorizmu (taylorjanske tvornice) kot znanstveno opredeljenemu globaliziranemu industrijskemu menedžmentu. ${ }^{39}$

37 Število zlogov po verzih - izvirnik: 10 / 6 / 8 / 6/ 10 / 8/ 9 / 12 / 6 / 7 / 9 / 7 / 9 / 4; hrv. prevod: $10 / 6 / 9 / 6 / 10 / 6 / 11 / 13 / 5 / 7 / 8 / 6 / 8 / 4$; it. prevod: $11 / 9 / 7 / 5 / 14 / 7 / 10 / 15 / 5 / 10 / 10 / 8 / 12 / 5$.

38 J. Vrečko, 2011: Srečko Kosovel ..., str. 425.

39 M. Juvan, 2009: Kosovelova referenca na Čapka in njen kontekst. »Primerjalna književnost«, št. 32/1, str. 181. 
Človek ni robot. ${ }^{40} \mathrm{~J}$. Vrečko opozarja še na eno dimenzijo konsa: odkriva možno zvezo z zgodnjim tigrovstvom in uporom Primorcev proti brezdušnemu fašizmu. ${ }^{41}$ Kons sestavlja pet kitic $\mathrm{z}$ različnim številom verzov $(6,5,3,2$ in 1 ; vseh je 17), ki se po dolžini razlikujejo; ${ }^{42} \mathrm{v}$ pesmi je 15 večinoma kratkih povedi (12 enostavčnih, 2 nestavčni in 1 dvostavčna). Med retoričnimi shemami naj omenim prestopno rimo $\mathrm{v}$ prvi kitici, tj. dresirati - dresure - mehanizirati kulture (v. 3-6), ki jo dopolnjuje glasovna podobnost (v. 3-4), in paralelizem $\mathrm{v}$ verzih 3 in 5, 4 in 6 (zadnji ni popoln). Med tipografsko zanimive elemente sodijo velike odebeljene črke v verzih $15-16$, kjer besedilo poteka vzporedno $\mathrm{v}$ dveh stolpcih, gl. 15, in kratica ${ }^{\mathrm{e}} \mathrm{R} \mathrm{U}^{\mathrm{e}} \mathrm{R}$ (v. 8), zapisana po izgovoru.

$\mathrm{V}$ hrvaščini je $\mathrm{v} 13$ verzih privzeti prevod. O drugih skladenjskih strategijah bi lahko govorili v štirih verzih, s po dvema spremembama enote (glagol se ne da - glagolska zveza nije moguće v. 3,5 ) in besedne zveze, in sicer glagolskega časa (sedanjik izbruhne - aorist banu v. 9) in števila (ed. opeke - mn. cigala v. 16), gl. 8-10. Sinonimija se pojavi le enkrat (izbruhniti - banuti v. 9), gl. 9. Retorične sheme in tipografske posebnosti so ohranjene. Po obliki sta si izvirnik in prevod podobna (gl. op. 42), po tipu povedi pa se ujemata.

(8) Zveri se ne da dresirati. - Zvijer nije moguće dresirati. (v. 3)

(9) Iz Homunkulusov izbruhne človek. — Iz Homunkulusā banu čovjek. (v. 9)

(10) HIŠA / IZ OPEKE. — KUĆA / OD CIGALA. (v. 15-16)

V italijanščini privzeti prevod vsebuje 12 verzov, druge skladenjske strategije pa pet. Med njimi prevladujejo stavčne spremembe: dve besednoredni (v. 3, 5), po ena stavčnočlenska (v. 4) in stavčno-polstavčna (v. 2), gl. 11-13; tem sledijo dve spremembi enote (glagol se da - glagolska zveza è possibile v. 3; predložna zveza za prirodo - samostalnik la natura v. 4), po ena sprememba stavčne zveze (vezalno priredje - gerundijski polstavek v. 2), transpozicija (samostalnik dresura - glagol addomesticare v. 4) in sprememba kohezije (izpust kazalnega zaimka to v. 13), gl. 11-14. V »rekonsu « se pojavljajo tri primeri sinonimije (dresirati - ammansire v. 3; ni - non si lascia, dresura - addomesticare v. 4), gl. 11-12. Retorične sheme (rima, paralelizma) v italijanskem prevodu niso ohranjene. Pri tipografsko zanimivih elementih je treba omeniti prevod

40 F. Zadravec, 1986: Srečko Kosovel ..., str. 161-163; B. Tokarz, 2004: Między destrukcja ..., str. 114; M. Juvan, 2009: Kosovelova referenca ..., str. 179.

41 J. Vrečko, 2011: Srečko Kosovel ..., str. 424-426.

42 Število zlogov po verzih - izvirnik: 9/5/9/8/11/8/8/6/11/6/8/6/9/8 / 5 / 7 / 5; hrv. prevod: $10 / 5 / 10 / 9 / 13 / 9 / 9 / 6 / 10 / 8 / 8 / 8 / 7 / 8 / 5 / 7 / 7$; it. prevod: $11 / 4 / 12 / 13 / 13 / 11 / 9 / 8 / 10 / 9 / 6 / 9 / 9 / 8 / 10 / 7 / 7$. 
kratice ${ }^{\text {er }} \mathrm{Re} U{ }^{\text {er }} \mathrm{Re}$ po izgovoru in ohranitev tipografske označenosti v verzih 14-15 (kljub premiku označenosti zaradi besednorednih zahtev), gl. 15. Oblikovno se italijanski prevod in izvirnik razlikujeta (gl. op. 42), po tipu povedi pa se načeloma ujemata (z izjemo polstavka iz v. 2).

(11) Zveri se ne da dresirati. - Non è possibile ammansire le belve. (v. 3)

(12) Za prirodo ni dresure. - La natura non si lascia addomesticare. (v. 4)

(13) in ga raztrgal. - sbranandolo. (v. 2)

(14) Človek: to je nova beseda. - L'uomo: è una parola nuova. (v. 13)

(15) Uničite taylorjanske Distruggete le fabbriche

TVORNICE! HIŠA IZ TAYLORISTICHE! UNA CASA DI

UNIČITE! OPEKE. DISTRUGGETE! MATTONI. (v. 14-16)

\subsection{Kons: 4}

Kons: 4 uvede obsojanje Einsteina v Bostonu: Boston naj bi bil prispodoba za kardinala W. H. O’Connella, ki je nasprotoval »brezbožni« (nevarni) Einsteinovi teoriji relativnosti, ${ }^{43}$ ta pa je Kosovelu pomenila pozitivno relativizacijo »dokončnega « in podporo neskončnosti »vsega fizisa in časa ${ }^{44}{ }^{44}$ Uvodu dela sledijo podobe političnih pregonov in sprememb, teroriziranje vojske in policije. $\mathrm{V}$ takšnem svetu so privilegirani veliki ljudje, medtem ko morajo majhni živeti po paragrafih. Najbrž tem svet prinaša - v odstavkih - kazni, zapore, pregnanstvo, tudi subjektu, ki pa mu jok (ko naslovi ljubico) ne predstavlja možnosti, temveč se vsemu protičloveškemu upre s svojim heroizmom, ${ }^{45} \mathrm{~s}$ svojo neomajnostjo, trdostjo. Kons tvori blok 24 različno dolgih verzov ${ }^{46}$ in 22 večinoma kratkih povedi (11 enostavčnih, 9 nestavčnih in 2 večstavčni). Med retoričnimi shemami sta dva paralelizma (s ponovitvijo): Relativiteta nevarna? / Kitajski študentje nevarni? (v. 3, 6) in Frajtar terorizira. / Žandar terorizira (v. 10-11);

43 R. Kodrič, 2011: Listkarstvo in politična invektiva med pobudniki Kosovelovega duhovnega in pesniškega zorenja. »Primerjalna književnost«, št. 34/1, str. 110.

44 F. Zadravec, 1986: Srečko Kosovel ..., str. 165-166.

45 F. Zadravec, 1986: Srečko Kosovel ..., str. 178, 183.

46 Število zlogov po verzih - izvirnik: 7 / $7 / 9 / 7 / 6 / 9 / 5 / 8 / 9 / 7 / 7 / 8 / 8 / 7 / 6$ /6/5/6/5/6/9/8/5/8; hrv. prevod: 8/6/7/7/6/8/5/10/9 / 8 / 7 / 7 / 9 /8/7/6/5/9/6/5/8/9/7/9; it. prevod: 6/6/12/7/6/13/6/8 / $7 / 9 / 8 / 6 / 10 / 11 / 9 / 6 / 6 / 8 / 5 / 7 / 7 / 8 / 8 / 9$. 
v verzih $15-17$ se pojavi še tipografski paralelizem: odebeljenemu znaku za odstavek $(\$)$ in simbolu obsojenca sledi navedba kazni (npr. $\$$ X: $14 d n i$ $v$ zapor v. 15).

V hrvaščini se privzeti prevod pojavlja v 22 verzih, v dveh pa so prisotne druge skladenjske strategije: dve stavčni spremembi, besednoredna (v. 13) in stavčnočlenska (v. 18), in ena sprememba enote (pridevnik zaprt - predložna zveza $u$ zatvoru v. 18), gl. 16-17. V »rekonsu« se pojavlja tudi en primer »sinonimije« (večji odmik, prim. frajtar — poreznik v. 10), gl. 18. Hrvaški prevod ohranja izhodiščni retorični shemi in tipografske posebnosti. Oblikovno sta izvirnik in prevod zelo podobna (gl. op. 46), po tipu povedi pa se ujemata.

(16) po svoje duše zakonih. - po zakonima svoje duše. (v. 13)

(17) 21 let sem bil zaprt -21 godinu bio sam u zatvoru. (v. 18)

(18) Frajtar terorizira. - Poreznik terorizira. (v. 10)

V italijanščini se privzeti prevod pojavlja v 15 verzih. Druge skladenjske strategije v ostalih devetih verzih vključujejo šest stavčnih sprememb, in sicer po tri besednoredne (v. 6, 18, 21) in stavčno-(proti)eliptične (v. 3, 6, 20), pet sprememb kohezije (dodajanje pomožnika essere v. 3, 6; izpust pomožnika biti v. 20; izpust svojilnega zaimka svoj v. 13; izpust kontaktnega medmeta hej v. 21), gl. 19-20, po eno transpozicijo (samostalnik vlade - zaimek ne v. 8) in spremembo enote (samostalniška zveza veliki ljudje - posamostaljeni pridevnik i grandi v. 12), gl. 21-22. Prevajalka se je v verzu 7 odločila za pragmatično spremembo informacije - v opombo je umestila zgoščeno informacijo o kratici SHS, gl. 24. $\mathrm{V}$ italijanskem prevodu na en paralelizem vpliva sprememba besednega reda, prim. La relatività è pericolosa? / Son pericolosi gli studenti cinesi? (v. 3, 6); tipografske posebnosti so ohranjene. Po verzih se izvirnik in prevod nekoliko razlikujeta (gl. op. 46), pri tipu povedi pa prihaja do treh odstopanj (dve stavčni povedi nam. nestavčnih v. 3, 6; ena nestavčna nam. stavčne v. 20).

(19) Kitajski študentje nevarni? - Son pericolosi gli studenti cinesi? (v. 6)

(20) Hej ljubica, ti bi jokala? - Tu, cara, piangeresti?

(21) Dosti vlad je že menjala - Molti ne ha già cambiati (v. 8)

(22) Veliki ljudje živijo - I grandi vivono (v. 12)

(23) SHS menja vlado. - SCS* cambia governo.

* SCS: Serbia, Croazia, Slovenia (Srbija, Hrvaška, Slovenija). 


\subsection{Kons (Truden evropski človek)}

V konsu subjekt opozarja pred nevarnostjo sodobne civilizacije, govori o zatonu dotedanje evropske civilizacije: ${ }^{47}$ truden evropski človek, izpraznjen človek krize, "materialist $«,{ }^{48}$ žalostno opazuje zaton (zlati večer) evropske civilizacije brez srca. ${ }^{49}$ Soočanje s krizo utruja (izmučena borba), kriza prazni $d u \check{s} s,{ }^{50}$ je boleča evropska civilizacija umira. Kons se konča s pozivom k človeški empatičnosti (usmiljenju) in $\mathrm{z}$ dvomom, negotovostjo ${ }^{51}-\mathrm{v}$ obliki retoričnega vprašanja $\mathrm{v}$ intelektual(izira)no reševanje eksistencialnih vprašanj (dvom $\mathrm{v}$ profesorsko razumevanje življenja). ${ }^{52} \mathrm{~V}$ konsu ima Kosovel funkcijo Atlasa sveta, kar se $\mathrm{v}$ romantičnem in ekspresionističnem svetovnem nazoru navezuje na razumevanje pesnika kot demiurga. ${ }^{53}$ Kons sestavlja blok 14 različno dolgih verzov ${ }^{54}$ in 11 povedi različnega tipa (6 nestavčnih, 4 enostavčne in 1 dvostavčna). Od retoričnih shem izpostavljam paralelizem z (leksikalno zrcalnim) nasprotjem Civilizacija je brez srca. / Srce je brez civilizacije (v. 6-7), ponovitev Usmiljenje! Usmiljenje! (v. 12) in primerjavo večer peče kot ogenj (v. 4).

$\mathrm{V}$ hrvaščini 13 verzov zaznamuje privzeti prevod; le v verzu 2 se nahaja stavčna sprememba besednega reda, gl. 24. Na ravni retoričnih shem v prevodu ne prihaja do sprememb. Po obliki (gl. op. 54) in po tipu povedi se hrvaški prevod in izvirnik ujemata.

(24) strmi žalostno v zlati večer, — žalosno zuri u zlatnu večer (v. 2)

47 F. Zadravec, 1986: Srečko Kosovel ..., str. 161; D. Poniž, 2003: Slovenske zgodovinske avantgarde med Podbevškom in Tankom. »Filologičeskie zametki«, št. 2/2, str. 175.

48 A. Adam, 2013: Kosovelov demokratični socializem. »Ustroj«, št. 5, str. 5-6.

49 Prim. D. Pavlič, 2005: Kosovel in moderna poezija: analiza podobja. »Primerjalna književnost«, št. 28/Posebna številka, str. 28. - Do civilizacije je imel Kosovel ambivalenten odnos: videl je njeno uporabno vrednost, hkrati pa pred njeno prevlado nad ljudmi postavljal individualnost; hvalil je svetle tovarne in obenem klical k njihovemu rušenju, ker se človek ne more mehanizirati, podobno kot se živali ne morejo dresirati. - Kons (Truden evropski človek) naj bi predstavljal sintezo podobe evropskega človeka, ki jo uokvirjata dve metafori: civilizacija je brez srca in srce je brez civilizacije človeka v kontekstu univerzuma, biologije in narave, družbe ali tehnike (civilizacije) zaznamujejo čustva, sočutje, empatija. Prim. B. Tokarz, 2004: Między destrukcja ..., str. 62, 115.

50 Prim. D. Pavlič, 2005: Kosovel ..., str. 29.

51 B. Tokarz, 2004: Między destrukcją ..., str. 60.

52 A. Adam, 2013: Kosovelov ..., str. 6.

53 B. Tokarz, 2004: Między destrukcja ..., str. 59.

54 Število zlogov po verzih - izvirnik: 7 / 9 / 7 / 6/ 1/ 10/10/6/6/ 7 / 4 / 8/ 5 / 7; hrv. prevod: $8 / 9 / 8 / 6 / 1 / 10 / 10 / 6 / 7 / 8 / 4 / 8 / 8 / 7$; it. prevod: $6 / 12 / 6 / 5 / 2 / 9 / 8 / 6 / 8 / 8 / 6 / 4 / 6 / 6$. 
V italijanščini se privzeti prevod nahaja v desetih verzih, medtem ko ostale štiri zaznamujejo druge skladenjske strategije: štiri stavčne spremembe, tj. po dve besednoredni (v. 4, 10) in stavčnočlenski (v. 2, 10), in dve spremembi enote (samostalniška zveza evropski človek - samostalnik un europeo v. 1; samostalnik večer - samostalniška zveza il fuoco della sera v. 10), gl. 25-27. Dva verza vsebujeta tri sinonimne izbire (strmi - contempla v. 2; izmučena borba - lotta massacrante v. 8; peče - arde v. 10), gl. 25-26. Med večinoma ohranjenimi retoričnimi shemami opozarjam na izpust primerjave (v. 10), gl. 26. Italijanski prevod in izvirnik sta si po verzih podobna (gl. op. 54), po tipu povedi pa se ujemata.

(25) strmi žalostno v zlati večer, - contempla tristemente l'aurata sera (v. 2)

(26) Večer peče kot ogenj. - Arde il fuoco della sera. (v. 10)

(27) od duše njegove - della sua anima (v. 4)

\subsection{Kons.Ikarus}

Kons po M. Šušteršič govori o Slovencih, njihovem značaju, usodi in perspektivi. Petkrat ponovljeni izraz Slovenec pomeni pripadnika naroda in časopis, značilnosti obeh pa so zamenljive: Slovenec je neangažiran, časopis Slovenec kupljiv, in obratno; ${ }^{55}$ prim. dvojnost brezciljnega Slovenca (pripadnika naroda) in Slovenca / črno obrobljenega (časopis). ${ }^{56}$ J. Vrečko se ob tem naveže še na Ikarja, ki ga Kosovel vidi »kot večni človekov konstruktivni projekt o človeku ptici in o uresničevanju umetniškega ustvarjalnega smisla ", in v konsu prepoznava »vzpon«: možnost preseganja stanja, v katerem se nahaja slovenstvo (in opozori na K. Juga, slovenskega Ikarja, ki je zaupal v spremembo narodnega značaja in si prizadeval za njegovo opolnomočenje, pokončnost), boj in akcijo Primorcev. $\mathrm{V}$ konsu bi lahko šlo tudi za nasprotje med K. Jugom in Slovenci, zlasti tistimi iz osrednje Slovenije, ki so po Rapalski pogodbi »tiščali glavo v pesek«, in za kritičen odnos do mednarodne politike. ${ }^{57}$ Po B. Tokarz kons hkrati razglaša konec brezciljnega Slovenca (Ta okrvavljeni človek je umrl. / Slovenec / črno obrobljeni). ${ }^{58}$ Kons tvorijo tri kitice $\mathrm{z}$ različnim številom verzov $(4,1,2$; vseh je 7), ki so različno dolgi, ${ }^{59}$ in šest kratkih povedi (5 nestavčnih, 1 enostavčna).

55 M. Šušteršič, 1988: Likovnost integralov Srečka Kosovela. »Slavistična revija«, št. 36/1, str. 62.

56 F. Zadravec, 1986: Srečko Kosovel ..., str. 180-181.

57 J. Vrečko, 2011: Srečko Kosovel ..., str. 417-424.

58 B. Tokarz, 2004: Między destrukcją ..., str. 124.

59 Število zlogov po verzih - izvirnik: $6 / 7 / 3 / 3 / 9 / 3 / 5$; hrv. prevod: 6 / 7 / 3/3/10/3/5; it. prevod: $7 / 7$ / 3/3/9/3/4. 
Ključna retorična shema v konsu je ponavljanje izraza Slovenec (v. 1-4, 6), ki je trikrat del paralelne zgradbe (v. 2-3, 6), kar poveča učinek ponavljanja.

Hrvaški prevod lahko označim kot v celoti privzet (ključna retorična shema je ohranjena); po obliki (gl. op. 59) in po tipu povedi se hrvaški prevod in izvirnik ujemata.

Tudi v italijanščini bi lahko govorili o privzetem prevodu v celoti. Poseben je verz 2 , ki vključuje pragmatično spremembo informacije: besedo Slovenec Sloveno ${ }^{*}$ je prevajalka pospremila z opombo (o časopisu Slovenec in o tem, zakaj ga je Kosovel uporabil), gl. 28. Oblikovno (gl. op. 59) in po tipu povedi se italijanski prevod in izvirnik ujemata.

(28) Brezciljni Slovenec. - Sloveno* senza meta. (v. 1)

* Kosovel si è servito del titolo del giornale cattolico Slovenec (Sloveno) che spesso suggeriva ai suoi lettori l'ubbidienza e la fiducia nel potere e l'umiltà nei confronti della religione e di Dio - per ironizzare amaramente sul carattere remissivo degli sloveni in genere. Il giornale inoltre soleva orlarsi di nero alle morti di persone importanti (Kosovel je uporabil naslov slovenskega katoliškega časopisa Slovenec — ki je svojim bralcem pogosto svetoval poslušnost in zaupanje $\mathrm{v}$ oblast in ponižnost $\mathrm{v}$ razmerju do vere in Boga, da bi z grenkobo ironiziral v splošnem popustljiv značaj Slovencev. Časopis je poleg tega ob smrti pomembnih osebnosti običajno izhajal s črnim robom).

\subsection{Kons (Premalo gibanja)}

V konsu Kosovel naslavlja vprašanje ženske očarljivosti, ki se verjetno nanaša na pesnikovo platonično ljubezen Fanico Obidovo. ${ }^{60}$ Subjekt se s svojo ljubeznijo sooča preveč pasivno in samotarsko (premalo gibanja, preveč samote). Ohranja jo na platonični ravni (povedati si z očmi, čar v nedostopnosti, ki odeva žensko kot skrivnostni pajčolan), kar omehča alkohol (zaziblje pajčolan pred sanjami). A to početje se konča neuspešno (račun brez krčmarja) - gre namreč za izjemno trenutno stanje ali pa subjektu zmanjka aktivnosti (anomalija volje). Kons sestavlja enovit blok 14 verzov, ki se po dolžini razlikujejo; ${ }^{61}$ v konsu je sedem različno kompleksnih povedi (po 3 dvostavčne in nestavčne, 1 tristavčna). Izrazitih retoričnih shem ali tipografskih posebnosti ni.

60 F. Zadravec, 1986: Srečko Kosovel ..., str. 73; B. Tokarz, 2004: Między destrukcją ..., str. 57.

61 Število zlogov po verzih — izvirnik: 9/6/10/7/6/7/9/8/9/9/9/7/6/7; hrv. prevod: $9 / 7 / 9 / 6 / 6 / 7 / 10 / 9 / 11 / 10 / 8 / 6 / 6 / 7$; it. prevod: $10 / 8 / 9 / 11 / 5 / 9 / 10 / 12 / 14 / 14 / 9 / 6 / 6 / 9$. 
V hrvaščini se privzeti prevod pojavlja v 13 verzih; le verz 2 vključuje spremembo priredne zveze (vezalno priredje - protivno priredje), kar je posledica sinonimne izbire (in - a), gl. 29. Oblikovno (gl. op. 61) se prevod in izvirnik ujemata, podobno pa načeloma velja tudi za tip povedi (z izjemo priredne zveze iz v. 2).

(29) in preveč samote. - a previše samoće (v. 2)

V italijanščini je privzeti prevod v sedmih verzih, ostalih sedem pa vključuje druge skladenjske strategije. Šest verzov zaznamuje sprememba stavčne zgradbe: v petih (v. 3-4, 6-8) pride do premika besed med verzi (morda zaradi želje po približanju dolžini izhodiščnih verzov), enkrat (v. 9) do spremembe stavčnih členov, gl. 30-31; v »rekonsu « se nahajajo še tri spremembe enote (samostalnik alkohol - samostalniška zveza fumi dell'alcol, samostalniška zveza moja glava - samostalnik testa v. 9; samostalniška zveza zvončast cvet - samostalnik una campanula v. 10), po ena transpozicija (pridevniški zaimek moja - samostalniški zaimek mi v. 9) in sprememba kohezije (dodajanje zaimka mio v. 10), gl. 31-32. V verzu 9 se pojavljata dve sinonimiji (alkohol - i fumi dell'alcol, vzkipeti - salire), gl. 31. Po dolžini verzov se italijanski prevod nekoliko razlikuje od izvirnika (gl. op. 61), po tipu povedi pa se besedili ujemata.

(30) ves čar ženske je v njeni / nedostopnosti, ki jo odeva - tutto il fascino di una donna / sta nella sua inaccessibilità (v. 6-7)

(31) ko vzkipi alkohol v moji glavi — quando i fumi dell'alcol mi salgono alla testa (v. 9)

(32) in se odpre srce ko zvončast cvet - e il mio cuore si schiude come una campanula (v. 10)

\section{Razprava in sklep}

Namen prispevka je bil analizirati in opredeliti izbrane konstruktivistične pesmi Srečka Kosovela v hrvaškem prevodu Josipa Ostija iz leta 2019 in italijanskem prevodu Jolke Milič iz leta 2000. Analiza je temeljila na prevajalskih strategijah A. Chestermana, ki so vključevale predvsem skladenjske spremembe, delno tudi pomenske in pragmatične, obliko in tip povedi. Analizo dopolnjuje celostna opredelitev prevodov $\mathrm{z}$ vidika preubeseditvenega razmerja med konsi in "rekonsi« ter globalnega prevajalskega pristopa. 
Pri prevajanju analiziranih konsov, tj. Kons: $M A \bar{S}$ (Naša mačka), Kons: N, Kons (Tiger), Kons: 4, Kons (Truden evropski človek), Kons.Ikarus in Kons (Premalo gibanja), se je J. Osti v veliki večini (97 od 105 verzov) odločil za privzeti prevod, tj. za oblikovno najbližjo prevodno možnost v hrvaščini; v celoti privzeti so prevodi Kons: $M A \bar{S}$ (Naša mačka), Kons: N, Kons.Ikarus. Tudi v ostalih štirih pesmih se je redko odločil za drugo skladenjsko strategijo: po trikrat se je odločil za spremembo stavčne zgradbe (dvakrat je spremenil besedni red, enkrat stavčne člene) in enote, dvakrat je spremenil zgradbo besedne zveze (glagolski čas, število) in enkrat stavčno zvezo. Leksikalno "rekonsi« večinoma sledijo izvirnim pesmim, na kar opozarjajo samo tri sinonimične izbire (le ena predstavlja večji pomenski odmik). Izpostavljene retorične sheme v konsih Kons: MĀ̄ (Naša mačka), Kons (Tiger), Kons: 4, Kons (Truden evropski človek), Kons.Ikarus je prevajalec ohranil (le v prvem konsu delno), prav tako tipografske posebnosti v Kons (Tiger) in Kons: 4. Po obliki so si konsi in hrvaški prevodi zelo podobni, v primeru Kons: $M A \bar{S}$ (Naša mačka), Kons (Truden evropski človek), Kons.Ikarus in Kons (Premalo gibanja) lahko govorim celo o ujemanju. Po tipu povedi se konsi in hrvaški »rekonsi« ujemajo.

Tudi J. Milič se je večinoma, a nekoliko redkeje kot J. Osti, odločala za privzeti prevod (oblikovno najbližjo prevodno rešitev v italijanščini) - tako je namreč prevedenih 69 od 105 verzov; v celoti privzet je prevod pesmi Kons.Ikarus. Italijanski »rekonsi« vključujejo več drugih skladenjskih strategij kot hrvaški: v italijanskih prevodih je 26 sprememb stavčne zgradbe (13 sprememb besednega reda, pet stavčnočlenskih sprememb, tri spremembe so povezane z eliptično oz. protieliptično zgradbo, po ena sprememba prehodnosti in sprememba iz stavčnosti v polstavčnost), ki vključujejo tudi tri verzne premike (premike besed v naslednji verz zaradi približevanja izhodiščni dolžini verzov); sledi jim 13 sprememb enote, deset sprememb kohezije, tri transpozicije in dve stavčnozvezni spremembi (opozorim naj, da spremembe načeloma ne predstavljajo velikih besedilnih preoblikovanj). Italijanski »rekonsi« $\mathrm{z}$ desetimi manjšimi sinonimičnimi izbirami večinoma ostajajo v izhodiščnih leksikalnih okvirih. Prevajalka se je poleg tega odločila za tri pragmatične spremembe informacije - v prevajalskih opombah je razložila ciljnemu bralstvu neznana družbeno-kulturna pojava (SHS, časopis Slovenec) in uredniško leksikalno izbiro (malahit nam. ametist) v pesmi Kons: $M A \bar{S}$ (Naša mačka). Izhodiščne retorične sheme so v italijanskih prevodih največkrat delno ohranjene, neohranjene so v prevodu Konsa (Tiger), medtem ko so v Konsu.Ikarus ohranjene v celoti; tipografske posebnosti v prevodih Konsa (Tiger) in Konsa: 4 so po drugi strani dosledno ohranjene (v prvem »rekonsu« prihaja do manjšega premika). Po obliki se izvirni konsi in italijanski prevodi lahko nekoliko razlikujejo, npr. Kons (Tiger), Kons: 4 in Kons (Premalo gibanja), lahko so si podobni kot v primerih Kons: $M A \bar{S}$ (Naša mačka), Kons: $N$ in Kons 
(Truden), medtem ko pri Konsu.Ikarus lahko govorimo o ujemanju. Čeprav zaradi čisto formalnih razlik med jezikoma prihaja do oblikovnih odstopanj, pa izvirni konsi in italijanski »rekonsi« večinoma učinkujejo - po mojem občutku - vizualno podobno. Po tipu povedi se izvirni konsi in prevodi ujemajo, le v Konsu:4 prihaja do delnega ujemanja.

Analiza na podlagi Chestermanovih prevajalskih strategij (z obliko in tipi povedi) omogoča precej natančno opredelitev besedilnih prevajalskih rešitev (s podobnostmi in razlikami) $\mathrm{v}$ hrvaških in italijanskih prevodih: $\mathrm{v}$ obeh jezikih prevladuje privzeti prevod, ki je pogostejši v hrvaščini; v italijanskih prevodih se pogosteje pojavijo druge skladenjske prevajalske strategije (gre sicer za nevelike spremembe), enako velja za sinonimijo in pragmatično spremembo informacije; hrvaški prevodi dosledneje ohranjajo izhodiščne retorične sheme in so oblikovno bližje izhodiščnim konsom; v obeh prevodih se tipi povedi in tipografske značilnosti ujemajo $\mathrm{z}$ izhodiščnimi. Postopkovno prevodno analizo pa je treba - za celovit prevodni pogled na hrvaške in italijanske prevode Kosovelih konsov - nadgraditi $\mathrm{z}$ analizo potencialnih razlogov za razlike med prevodi in $\mathrm{z}$ opredelitvijo celostnega razmerja med izvirniki in prevodi ter globalnega prevajalskega pristopa.

Do razlik v prevajalskih strategijah med hrvaškimi in italijanskimi prevodi verjetno prihaja zaradi prepleta razlogov. Prvi razlog je razlika med jeziki, zaradi katere se je J. Osti v hrvaščini enostavneje približal izhodiščnemu besedilu na več ravneh kot J. Milič, ki ji je privzeti prevod ponekod že sam po sebi predstavljal jasnejši formalni odmik od izhodiščnega besedila in je prej stopal v konkurenčno razmerje $\mathrm{z}$ drugimi prevodnimi možnostmi, obenem pa je npr. leksikalno sledenje izvirniku lahko vplivalo na večji odmik od izhodiščne oblike ali retorične sheme. Drugi potencialni razlog je slogovno vrednotenje prevodnih rešitev - do odmikov od privzetega prevoda ali izbire sinonimije lahko prihaja zaradi iskanja jezikovnih sredstev, ki so prevajalcu ali prevajalki slogovno bližje (morda manj zaznamovani, primernejši ipd.), hkrati pa izbira temelji tudi na poznavanju slogovnih možnosti in njihove vloge v ciljnem jeziku in ciljni književni tradiciji ${ }^{62}$ (tudi primerjalno $\mathrm{z}$ izhodiščno tradicijo; od tu morda pogostejša izbira »neprivzetega « prevoda ali sinonimije v italijanščini). Nenazadnje pa je treba omeniti še interpretacijo, ki lahko pelje v alternativno preubeseditev posameznega besedilnega segmenta, in informativno-interaktivno vlogo, ki je najbrž vplivala na prevajalske opombe (pragmatična strategija spremembe informacije) J. Milič.

Kljub »prevajalskim postopkovnim « razlikam pa lahko sklenem, da so tako hrvaški kot italijanski »rekonsi« - glede na izvirnike - poustvarjalni prevodi

62 Prim. M. Ožbot, 2018: O Kosovelovi »evropskosti« ..., str. 208. 
(po F. R. Jonesu) oz. verodostojni prevodi (po A. Lefeveru), metapesmi, ki skušajo mimetično poustvariti izhodiščno obliko (po J. Holmesu). V obeh prevodih lahko prepoznavamo prevladujoč potujitveni prevajalski pristop (globalno prevajalsko strategijo): ${ }^{63}$ oba prevajalca sta načeloma skušala ohranjati značilnosti Kosovelovih konsov - njihovo zgradbo, oblikovanost, besedje, vsebino in sporočilo (pa naj bo osebnoizpovedno in ljubezensko, univerzalno, narodno -civilizacijsko in družbenoetično) - in jih v njihovih izhodiščnih razsežnostih predstaviti ciljnemu bralstvu. ${ }^{64}$

\section{Bibliografija}

Adam A., 2013: Kosovelov demokratični socializem. »Ustroj«, št. 5, str. 4-22.

Alekseeva I. S., 2008: Tekst i perevod. Voprosy teorii. Moskva, Meždunarodnye otnošenija.

Arduini S., Stecconi U., 2007: Manuale di traduzione. Roma, Carocci.

Bassnett S., 2002: Translation Studies. London/New York, Routledge.

Bibliografski sistem COBISS. Dostopno na internetu: https://plus.si.cobiss.net/ [dostop: 11. 01. 2021].

Biografski leksikon Primorci.si. Dostopno na internetu: http://www.primorci.si/ [dostop: 11. 01. 2021].

Boase-Beier J., 2013: Poetry translation. V: C. Millán, F. Bartrina, ed.: The Routledge Handbook of Translation Studies. London/New York, Routledge, str. 475-487.

Chesterman A., 1997: Memes of Translation. Amsterdam/Philadelphia, John Benjamins.

Dimkovska L., 2005: Književnost priseljencev v Sloveniji - njene značilnosti in položaj v slovenski kulturi. »Dve domovini«, št. 22, str. 59-78.

Hatim B., 2001: Teaching and Researching Translation. Harlow, Pearson Education.

Holmes J., 1988: Translated!: Papers on Literary Translation and Translation Studies. Amsterdam, Rodopi.

63 Za prevode J. Milič prim. M. Ožbot, 2018: O Kosovelovi »evropskosti« ..., str. 212.

$64 \mathrm{Za}$ bolj objektiven primerjalni pogled na Kosovelove prevode bi bilo v prihodnosti smiselno upoštevati večji nabor pesmi, ki bi razkril dodatne razlike (ali pa večje podobnosti) med njihovimi besedilnimi značilnostmi ( $\mathrm{v}$ odnosu do izvirnikov) in osvetlil, kako posamezni prevajalci uresničujejo svojo prevajalsko »vizijo«, kakšne so pri tem njihove omejitve (kakšna je vloga jezika), katerim vidikom dajejo prednost itn. 
Jan Z., 2000: Poznavanje slovenske književnosti v Italiji po letu 1945. Ljubljana, Založba Rokus/Slavistično društvo Slovenije.

Jan Z., 2001: Cankar, Kosovel, Zlobec in Ljubka Šorli pri Italijanih ter Bibliografski dodatek. Ljubljana, Založba Rokus/Slavistično društvo Slovenije.

Javna agencija za knjigo. Dostopno na internetu: https://www.jakrs.si/ [dostop: 11. 01.2021].

Jones F. R., 2011: Poetry translation. V: Y. Gambier, L. van Doorslaer, ur.: Handbook of Translation Studies 2. Amsterdam/Philadelphia, John Benjamins, str. $117-122$.

Juvan M., 2009: Kosovelova referenca na Čapka in njen kontekst. »Primerjalna književnost «, št. 32/1, str. 177-192.

Kodrič R., 2011: Listkarstvo in politična invektiva med pobudniki Kosovelovega duhovnega in pesniškega zorenja. "Primerjalna književnost«, št. 34/1, str. $81-116$.

Kocijančič Pokorn N., 1998: Beyond the Avant-Garde and Expressionism: Srečko Kosovel's Integrals. V: S. Kosovel: Integrals. N. Kocijančič Pokorn, K. Jerin, P. Burt, prev. Ljubljana, Slovene Writers' Association, str. 11-19.

Kos J., 1976: Pregled slovenskega slovstva. Ljubljana, DZS.

Kosovel S., 2000: Ves svet je kakor - Tutto il mondo è come. J. Milič, ur. in prev. Sežana, Občina Sežana.

Kosovel S., 2019: Integrali. J. Osti, prev. Zagreb, MeandarMedia.

Košuta M., 2011: Come un razzo rosso ... V: S. Kosovel: Ostri ritmi - Aspri ritmi. J. Milič, ur. in prev. Trieste, ZTT EST, str. 7-53.

Košuta M., 2014: »Le drugo ime za ljubezen ...«. Novejše knjižno italijanjenje slovenskega leposlovja (2000-2013). »Przekłady literatur słowiańskich«, št. 5/1, str. 218-243.

Mugerli M., 2005: Slovenski prevodi literarnih del priseljenskih avtorjev po letu 1990. "Dve domovini«, št. 22, str. 79-93.

Ožbot M., 2011: Dwarfs in Giants' Lands: Some Observations on Translating Minor Literatures into High-Impact Cultures - The Case of Slovene Literature in Italy. »Meta«, št. 56/3, str. 511-525.

Ožbot M., 2018: O Kosovelovi »evropskosti in še posebej o dveh nedavnih prevodih njegove poezije v italijanščino. V: I. Žunkovič, T. Smolej, ur.: Življenje med antiko in avantgardo: zbornik ob jubileju Janeza Vrečka. Ljubljana, ZZFF, str. 203-212.

Pavlič D., 2005: Kosovel in moderna poezija: analiza podobja. »Primerjalna književnost«, št. 28/Posebna številka, str. 19-34.

Pogorevc P., ur., 2006: Ten Authors from Slovenia. Ljubljana, Chamber of Commerce and Industry of Slovenia.

Poniž D., 2003: Slovenske zgodovinske avantgarde med Podbevškom in Tankom. »Filologičeskie zametki«, št. 2/2, str. 165-180. 
Regijski portal Kamra. Dostopno na internetu: https://www.kamra.si/digitalne -zbirke.html [dostop: 11. 01. 2021].

Šušteršič M., 1988: Likovnost integralov Srečka Kosovela. "Slavistična revija«, št. $36 / 1$, str. $61-79$.

Tokarz B., 2004: Między destrukcją a konstrukcja. O poezji Srečka Kosovela $w$ kontekście konstruktywistycznym. Katowice, Wydawnictwo Uniwersytetu Śląskiego.

Vrečko J., 2011: Srečko Kosovel. Monografija. Ljubljana, Založba ZRC/ZRC SAZU. Zadravec F., 1986: Srečko Kosovel 1904-1926. Koper/Trst, Založba Lipa/ZTT.

\section{Robert Grošelj}

\section{»Rekonsi«: prevodi Kosovelovih konsov in Chestermanove prevajalske strategije}

POVZETEK | Prispevek je posvečen analizi italijanskih in hrvaških prevodov izbranih konstruktivističnih pesmi (konsov) Srečka Kosovela, enega najpomembnejših slovenskih pesnikov (gre za sedem konsov v italijanskem prevodu Jolke Milič in hrvaškem prevodu Josipa Ostija). Prevedeni konsi (»rekonsi«) so bili analizirani glede na prevajalske strategije A. Chestermana (predvsem skladenjske, deloma tudi pomenske in pragmatične), obenem pa je bilo opredeljeno celostno prevodno razmerje med izhodiščnimi pesmimi in prevodi ter globalni prevajalski pristop. Analiza je pokazala, da tako $\mathrm{v}$ hrvaških kot $\mathrm{v}$ italijanskih prevodih Kosovelovih konsov prevladuje privzeti prevod, ki je pogostejši v hrvaščini; v italijanskih prevodih se pogosteje pojavijo druge skladenjske prevajalske strategije, enako velja za sinonimijo in pragmatično spremembo informacije; hrvaški prevodi dosledneje ohranjajo izhodiščne retorične sheme in so oblikovno bližje izhodiščnim konsom; v obeh prevodih se tipi povedi in tipografske značilnosti ujemajo z izhodiščnimi. Razlogi za razlike med hrvaškimi in italijanskimi prevodi lahko ležijo $v$ jezikovnih razlikah, slogovnem vrednotenju prevodnih rešitev (v kontekstu ciljnega jezika in ciljne književne tradicije), interpretaciji in informativno-interaktivni vlogi prevajalca. Kljub razlikam pa lahko tako hrvaške kot italijanske "rekonse « - glede na izvirne pesmi - označimo kot poustvarjalne prevode (po F. R. Jonesu) oz. verodostojne prevode (po A. Lefeveru), kot metapesmi, ki skušajo mimetično poustvariti izhodiščno obliko (po J. Holmesu). Poleg tega lahko oboje prevode obravnavamo kot zvečine potujitvene: »rekonsi« skušajo ohranjati lastnosti Kosovelovih konsov — njihovo zgradbo, obliko, vsebino in sporočilo - in jih tako v njihovi večplastni razsežnosti predstaviti ciljnemu bralstvu.

KLJUČNE BESEDE | Srečko Kosovel, konstruktivistične pesmi, hrvaški prevodi, italijanski prevodi, prevajalske strategije, Andrew Chesterman 


\section{Robert Grošelj \\ The "Re-Conses": Translations of Srečko Kosovel's Constructivist Poems and Andrew Chesterman's Translation Strategies}

SUMMARY | The article deals with the analysis of Italian and Croatian translations of selected constructivist poems (the "conses") by Srečko Kosovel, one of the most important Slovene poets (the analysed poems include seven "conses", translated in Italian and Croatian by Jolka Milič and Josip Osti, respectively). The translated "conses" (the "re-conses") were analysed by using Andrew Chesterman's translation strategies (mainly syntactic, partly also semantic and pragmatic); in addition, the general translation relationship between the source poems and their translations as well as the general translation approach were established. The analysis has shown that both Croatian and Italian translations include mostly literal (default) translations, which are more frequent in Croatian "re-conses"; Italian translations include more frequently other syntactic translation strategies as well as synonyms and pragmatic information changes; Croatian translations respect the source rhetorical schemes more consistently and are formally closer to the original poems; the source sentence-clause types and typographic features are preserved in both Croatian and Italian translations. The main reasons for differences between Croatian and Italian translations may lay in language distance, stylistic evaluation of translation options (in the context of the target language and the target literary tradition), interpretation and in translator's informative-interactive role. Despite differences, Croatian as well as Italian "re-conses" can be - with respect to Kosovel's source poems - described as recreative translations (according to F. R. Jones) or literal translations (according to A. Lefevere), as metapoems which strive to recreate mimetically the original form (according to J. Holmes). Besides that, both translations can be viewed as predominantly foreignizing: the "re-conses" strive to preserve the features of Kosovel's "conses" - their structure, form, content and message - and to present their multifaceted dimensions to the target readership.

KEYWORDS | Srečko Kosovel, constructivist poetry, Croatian translation, Italian translation, translation strategies, Andrew Chesterman

ROBERT GROŠELJ | rojen leta 1978 v Postojni (Slovenija), docent na Oddelku za prevajalstvo Filozofske fakultete Univerze v Ljubljani (Slovenija); raziskovalec italijanskega in slovanskih jezikov in književnosti. Ukvarja se predvsem $\mathrm{z}$ jezikoslovnimi vidiki prevajanja in slovenskimi prevodi $\mathrm{v}$ zgodovinski perspektivi; njegovo raziskovanje sega tudi na področje kontrastivnega jezikoslovja (predvsem slovensko-slovanskega in slovensko-italijanskega) in na primerjalno skladnjo slovanskih jezikov. Robert Grošelj je objavil več znanstvenih prispevkov in je (so)avtor dveh monografij: Vezava glagolov umevanja $v$ slovanskih jezikih (2011) in Lipalja vas in njena slovenska govorica (soavtor; 2016). 